\section{The SARS-CoV-2 epidemic, a school case for public health}

\author{
Philippe Chossegros* \\ Service de Médecine Pénitentiaire, Médecin des hôpitaux, Hospices Civils de Lyon, Le Grand Revoyet, \\ 69310 Pierre-Bénite, France
}

Received: 29 September, 2020

Accepted: 02 October, 2020

Published: 05 October, 2020

*Corresponding author: Philippe Chossegros, Service de Médecine Pénitentiaire, Médecin des hôpitaux, Hospices Civils de Lyon, Le Grand Revoyet, 69310 Pierre-Bénite, France,

E-mail:Philippe.chossegros@chu-lyon.fr; chossegros.p@gamil.com

ORCID: https://orcid.org/0000-0002-0098-8843

https://www.peertechz.com
The covid-19 epidemic has evolved differently depending on the responses to it. This heterogeneity and changes in recommendations have blurred the messages facilitating the emergence of fake news and conspiracy theories.

\section{Public health and the liberal state: The american para- dox}

The biomedical model explains the predominance of the pharmaceutical industry and the low resources allocated to public health research almost exclusively financed by the States. In a 2013 general review of non-pharmacological means of influenza prevention, Killingley and Nguyen-VanTam noted that a series of surveys to date have « failed to provide definitive answers and key questions remain. Reasons for this include the fact that many studies have not sought to investigate routes of transmission as a primary objective (instead, they have evaluated specific interventions) and that fieldwork in natural settings, specifically assessing the dynamics and determinants of transmission between humans, has been limited » [1]. During a debriefing of the 2009 influenza epidemic, Professor Delfraissy acknowledged the lack of solid data to understand the course and control of epidemics and the need to develop research in this field [2]. He insisted on the limited budgets of European governments, which probably do not amount to a tenth of that of the USA (France: €12.5M, Germany: €20M, United Kingdom: €15M, USA: \$700M). This difference would be even greater if one considered the shares allocated to "basic" research. For influenza, almost all animal models and in vitro models are funded by US federal agencies. They also fund epidemiological research conducted outside the territory of the United States. While the USA is regarded as the model of an ultraliberal society, the funding of research explains this paradoxical situation. Numerous agencies with large budgets of their own and very competent department set priorities, finance laboratories and organise partnerships with industry instead of leaving these choices to industry through tax breaks [3]. This organisation explains the dynamism of the major American universities that benefit also from tax exemptions linked to philanthropy [4]. Although the economic returns on investment are difficult to assess, they are part of American soft power with its international stranglehold on public health which has proved to be dissociated from internal political decisions [5].

\section{The role of previous pandemics}

The course of previous viral pandemics has led us to believe that a control would always be possible, leaving sufficient time to get organised: Responses to the last two influenza epidemics of 1976 and 2009 had been disproportionate, leading to severe criticism of political decisions $[2,6]$. The first had caused few cases and the second few deaths $(18,156$ deaths in 156 countries). On the other hand, both coronavirus epidemics were quickly brought under control by coercive measures implemented outside Western countries [7,8]. They may explain the differences in initial responses between East and West.

\section{A gap in health surveillance}

In France as in Italy, the first cases of Chinese origin did not cause the epidemics. The introduction of the virus was undoubtedly earlier and was only sought after at a time when the virus was already widely present in the population $[9,10]$, explaining the differences observed in April between the west and east of the European continent.

\section{Inappropriate and contradictory messages become in- comprehensible}

Communication: Key concepts were debated, which delayed the making of "good" decisions. They concerned the 
presence of asymptomatic and presymptomatic forms, aerial transmission, social distancing, and the interest of masks involving the communication of international agencies : « Seriously people-STOP BUYING MASKS! began a 29 February tweet from U.S. Surgeon General Jerome Adams. The World Health Organization and U.S. Centers for Disease Control and Prevention (CDC) have both said that only people with COVID-19 symptoms and those caring for them should wear mask while the director of the Chinese Center for Disease Control and Prevention, disagreed and Health authorities in parts of Asia have encouraged all citizens to wear masks in public to prevent the spread of the virus, regardless of whether they have symptoms » [11]. « Leading health agencies including the World Health Organization and the European Center for Disease Prevention and Control provided contradictory and sometimes misleading advice. A crucial public health discussion devolved into a semantic debate over what to call infected people without clear symptoms. The two-month delay was a product of faulty scientific assumptions, academic rivalries and, perhaps most important, a reluctance to accept that containing the virus would take drastic measures »[12].

\section{What was known?}

Pre- and asymptomatic forms were well known. For influenza, the actual number of cases was 20 to 50 times higher than that of clinical surveillance [13]. The difficulty of changing one's beliefs is illustrated by the original $35.5 \%$ inhospital mortality [14] attributed to MARS-CoV, whereas many asymptomatic cases had been discovered $[15,16]$.

The aerial transmission admitted for decades for tuberculosis had been indisputably demonstrated for influenza by the presence of viruses in aerosols produced by patients $[17,18]$ and by animal models $[19,20]$. Aerial transmission of SARS-CoV-1 was considered probable in 3 clinical studies [21].

Social distancing which was promoted from the beginning of the epidemic had never been evaluated [22]. Evidence of the value of handwashing and mask use was better documented without accurate measurement of their effectiveness due to the insufficient quality of the studies, which never eliminated all confounding variables $[1,22]$. Wearing a mask reduces the production of viruses. (18) Wearing masks by infected persons provided much greater protection than masks worn by recipients [23]. It limits, without making them disappear, the risks of contamination provided it is worn continuously [23].

\section{What we have learned since?}

A few examples confirm the validity of maximalist measures and of the utility of masks the actual incidence is much higher than the symptomatic cases [24], aerosolized fomites are contagious [25,26], Quarantine and stay at home order are effective [27-29], mask could reduce the inoculum and sympoms [30], mask continuous wearing is the most effective prevention [31] even if their are cloth mask [32,33].

\section{Conclusion}

Returning to the course of the SARS-CoV-2 epidemic, it is clear that the only truly effective responses were rapid, imposing all possible measures, without questioning their respective effectiveness, at a time when the spread of the virus was still limited. Delays in diagnosing the epidemic, discordant positions of the experts, lack of masks and belief that radical measures could not be accepted have led to a preference for prevention measures whose effectiveness was least proven (hand washing, social distance). Mistaken messages, the content of which it is difficult to know if they were linked to insufficient knowledge of the experts or to their belief in the population's inability to understand and/or apply them, have undermined confidence and favoured fake news, preparing the way for the curent resumption of the epidemic.

\section{References}

1. Smith SM, Sonego S, Wallen GR, Waterer G, Cheng AC, et al. (2015) Use of non-pharmaceutical interventions to reduce the transmission of influenza in adults: A systematic review. Respirology 20: 896-903. Link: https://bit.ly/2GvSxYi

2. Killingley B, Nguyen-Van-Tam J (2013) Routes of influenza transmission. Influenza Other Respir Viruses 42-51. Link: https://bit.ly/36qALk9

3. La grippe $A(\mathrm{H} 1 \mathrm{~N} 1)$ Retours sur " la première pandémie du XXle siècle » (rapport) sénat. Link: https://bit.ly/3jrYsfJ

4. Mazzucato M (2014) The entrepreneurial State : debunking public vs private sector myth. Anthem Press.

5. Vallely P (2020) How philanthropy benefits the super-rich. The guardian. Link: https://bit.ly/2GhVps4

6. Nuzzo JB, Bell JA, Cameron EE (2020) Suboptimal US Response to COVID-19 Despite Robust Capabilities and Resources. JAMA. Link: https://bit.ly/3nccODq

7. Sencer DJ (2011) Perspective: Swine-origin influenza: 1976 and 2009. Clin Infect Dis 52: S4- S7. Link: https://bit.ly/3n7AfOd

8. Donnelly CA, Fisher MC, Fraser C, Ghani AC, Riley S, et al. (2004) Epidemiological and genetic analysis of severe acute respiratory syndrome. Lancet Infect Dis 4: 672-683. Link: https://bit.ly/34hSI7s

9. Omrani AS, Al-Tawfiq JA, Memish ZA (2015) Middle East respiratory syndrome coronavirus (MERS-CoV): animal to human interaction. Pathog Glob Health 109: 354-362. Link: https://bit.ly/30scEhm

10. Deslandes A, Berti V, Tandjaoui-Lambotte Y, Alloui C, Carbonnelle E, Zahar JR, et al. (2020) SARS-CoV-2 was already spreading in France in late December 2019. Int J Antimicrob Agents 55: 106006. Link: https://bit.ly/34dWOYK

11. Valenti L, Bergna A, Pelusi S, Facciotti F, Lai A, et al. (2020) SARS-CoV-2 seroprevalence trends in healthy blood donors during the COVID-19 Milan outbreak. medRxiv. Link: https://bit.ly/2GaPaX

12. Servick K (2020) Would everyone wearing face masks help us slow the pandemic? AAAS. Link: https://bit.ly/36rKhn6

13. Apuzzzo M, Gebrekidan S, Kirkpatrick DD (2020) How the World Missed Covid19's Silent Spread. The New York Times. Link: https://bit.ly/36sscVZ

14. Baguelin M, Hoschler $K$, Stanford E, Waight $P$, Hardelid $P$, et al. (2011) Age specific incidence of A/H1N1 2009 influenza infection in England from sequential antibody prevalence data using likelihood-based estimation. PLoS One 6: e17074. Link: https://bit.ly/33opSxn

15. Xie M, Chen Q (2020) Insight into 2019 novel coronavirus - An updated interim review and lessons from SARS-CoV and MERS-CoV. Int $\mathrm{J}$ Infect Dis 94: 119 124. Link: https://bit.ly/3ncu6Q 
16. Alshukairi AN, Zheng J, Zhao J, Nehdi A, Baharoon SA, et al. (2018) High Prevalence of MERS-CoV Infection in Camel Workers in Saudi Arabia. mBio 9: e01985-18. Link: https://bit.ly/33nOFSf

17. Omrani AS, Al-Tawfiq JA, Memish ZA (2015) Middle East respiratory syndrome coronavirus (MERS-CoV): animal to human interaction. Pathog Glob Health 109: 354-362. Link: https://bit.ly/3cRamx7

18. Fabian P, McDevitt JJ, DeHaan WH, Fung RO, Cowling BJ, et al. (2008) Influenza virus in human exhaled breath: an observational study. PLoS One 3 : e2691. Link: https://bit.ly/2HNgQSh

19. Milton DK, Fabian MP, Cowling BJ, Grantham ML, McDevitt JJ (2013) Influenza virus aerosols in human exhaled breath: particle size, culturability, and effect of surgical masks. PLoS Pathog 9: e1003205. Link: https://bit.ly/3iq3E2e

20. Turgeon N, Hamelin MÈ, Verreault D, Lévesque A, Rhéaume C, et al. (2019) Design and Validation with Influenza A Virus of an Aerosol Transmission Chamber for Ferrets. Int J Environ Res Public Health 16: 609. Link: https://bit.ly/2ESpQ7y

21. Mubareka S, Lowen AC, Steel J, Coates AL, García-Sastre A, et al. (2009) Transmission of influenza virus via aerosols and fomites in the guinea pig model. J Infect Dis 199: 858-865. Link: https://bit.ly/2Gw8eyl

22. Morawska L, Cao J (2020) Airborne transmission of SARS-CoV-2: The world should face the reality. Environ Int 139: 105730. Link: https://bit.ly/3la2JVM

23. Jefferson T, Del Mar CB, Dooley L, Ferroni E, Al-Ansary LA, et al. (2011) Physical interventions to interrupt or reduce the spread of respiratory viruses. Cochrane Database Syst Rev 2011: CD006207. Link: https://bit.ly/3la2IBc

24. Macintyre CR, Chughtai AA (2020) A rapid systematic review of the efficacy of face masks and respirators against coronaviruses and other respiratory transmissible viruses for the community, healthcare workers and sick patients. Int J Nurs Stud 108: 103629. Link: https://bit.ly/3ik30mV

25. Blackburn J, Yiannoutsos CT, Carroll AE, Halverson PK, Menachemi N (2020)
Infection Fatality Ratios for COVID-19 Among Noninstitutionalized Persons 12 and Older: Results of a Random-mple Prevalence Study. Ann Intern Med M20 5352. Link: https://bit.ly/3ioRFIR

26. Asadi S, Gaaloul ben Hnia N, Barre RS, et al. (2020) Influenza A virus is transmissible via aerosolized fomites. Nat Commun 11: 4062. Link: https://go.nature.com/33mTlrs

27. Kaiser J (2020) Can you catch COVID-19 from your neighbor's toilet?. Link: https://bit.ly/3cS7Aru

28. Nussbaumer-Streit B, Mayr V, Dobrescu Al, Chapman A, Persad E, et al. (2020) Quarantine alone or in combination with other public health measures to control COVID-19: a rapid review. Cochrane Database of Systematic Reviews. Cochrane Database Syst Rev 4: CD013574. Link: https://bit.ly/2GbKccR

29. Sen S, Karaca-Mandic P, Georgiou A (2020) Association of Stay-at-Home Orders With COVID-19 Hospitalizations in 4 States. JAMA 323: 2522-2524. Link: https://bit.ly/3ncbhNG

30. Lyu W, Wehby GL (2020) Comparison of Estimated Rates of Coronavirus Disease 2019 (COVID-19) in Border Counties in lowa Without a Stay-at-Home Order and Border Counties in Illinois With a Stay-at-Home Order. JAMA Netw Open 3: e2011102. Link: https://bit.ly/33o98qk

31. Gandhi M, Beyrer C, Goosby E (2020) Masks Do More Than Protect Others During COVID-19: Reducing the Inoculum of SARS-CoV-2 to Protect the Wearer. J Gen Intern Med 1-4. Link: https://bit.ly/30usFTX

32. Doung-Ngern $P$, Suphanchaimat $R$, Panjangampatthana $A$, Janekrongtham $C$, Ruampoom D, et al. (2020) Case-Control Study of Use of Personal Protective Measures and Risk for Severe Acute Respiratory Syndrome Coronavirus 2 Infection, Thailand. Emerg Infect Dis 26. Link: https://bit.ly/30rtNaN

33. Clase CM, Fu EL, Joseph M, Beale RCL, Dolovich MB, et al. (2020) Cloth Masks May Prevent Transmission of COVID-19: An Evidence-Based, Risk-Based Approach. Ann Intern Med 173: 489-491. Link: https://bit.ly/33kZSD4
Discover a bigger Impact and Visibility of your article publication with Peertechz Publications

Copyright: (c) 2020 Chossegros P. This is an open-access article distributed under the terms of the Creative Commons Attribution License, which permits unrestricted use, distribution, and reproduction in any medium, provided the original author and source are credited. 